\title{
Effect of Genetic Merit and Concentrate Supplementation on Grass Intake and Milk Production with Holstein Friesian Dairy Cows
}

\author{
J. Kennedy, ${ }^{\star} †$ P. Dillon, ${ }^{*}$ L. Delaby,‡ P. Faverdin,‡ \\ G. Stakelum, ${ }^{*}$ and M. Rath $†$ \\ *Dairy Production Department, Teagasc, \\ Moorepark Production Research Center, Fermoy, Co. Cork, Ireland \\ †Department of Animal Science, Faculty of Agriculture, \\ University College Dublin, Belfield, Dublin 4, Ireland \\ †INRA, UMR Production du Lait, 35590 St. Gilles, France
}

\begin{abstract}
A total of 48 high genetic merit (HM) and 48 medium merit (MM) cows, each given a low (LC), medium (MC), or high (HC) level of concentrate supplementation, were used in a split-plot design experiment, which was run in three consecutive years, to evaluate animal production responses. Individual cow intakes were estimated twice each year while at pasture; measurement period 1 (MPI) was in May/June, and measurement period 2 (MP2) was in early September, corresponding on average to d 110 and 200 of lactation, respectively. In MP1, cows were offered 0 (LC), $3(\mathrm{MC})$, and $6 \mathrm{~kg}(\mathrm{HC})$, whereas in MP2 the levels were 0 (LC), 0 (MC), and 4 $\mathrm{kg}(\mathrm{HC})$ of concentrate daily. Genotype had a significant effect on all milk production parameters in MP1 and MP2. The HM cows had the highest yield of milk, fat, protein, and lactose, whereas the MM cows had the highest milk fat, protein, and lactose concentrations. The HM cows had significantly higher grass dry matter intake (GDMI) estimates. In MP1, the average responses, per kg concentrate dry matter, was $+1.10 \mathrm{~kg}$ of milk, $+0.038 \mathrm{~kg}$ of protein, $+0.032 \mathrm{~kg}$ of fat. The corresponding values in MP2 were $+0.94 \mathrm{~kg}$ of milk, $+0.037 \mathrm{~kg}$ of protein, and $+0.025 \mathrm{~kg}$ of fat. The response to concentrate was linear and independent of preexperimental milk yield. In MP1, the partial regression coefficients relating daily GDMI to an increase in $1 \mathrm{~kg}$ of preexperimental milk yield (PMY), preexperimental BW (PBW), and concentrate intake (CI) were 0.123 , 0.006 , and -0.54 , respectively, whereas the corresponding values in MP2 were $0.190,0.007$, and -0.444 , respectively. This study indicates that with high yielding dairy cows, on gras only GDMI of $17 \mathrm{~kg}$ of supporting milk yield of $30-\mathrm{kg} / \mathrm{d}$ is achievable. In this scenario,
\end{abstract}

Received February 13, 2002.

Accepted April 3, 2002.

Corresponding author: J. Kennedy; e-mail: jkennedy@moorepark. teagasc.ie. concentrate supplementation will result in lower substitution rates, and higher milk yield response than previously published with lower yielding cows.

(Key words: genetic merit, concentrate supplementation, grass dry matter intake)

Abbreviation key: $\mathbf{C I}=$ concentrate intake, $\mathbf{D M D}=$ dry matter digestibility, GDMI = grass dry matter intake, GOMI = grass organic matter intake, $\mathbf{H C}=$ high concentrate, $\mathbf{H M}=$ high merit, $\mathbf{L C}=$ low concentrate, $\mathbf{L N}=$ lactation number, $\mathbf{M C}=$ medium concentrate, MADF $=$ modified acid detergent fiber, $\mathbf{M M}=$ medium merit, $\mathbf{M P}=$ measurement period, $\mathbf{O M D}=$ organic matter digestibility, $\mathbf{P B W}=$ preexperimental $\mathbf{B W}, \mathbf{P D}=$ predicted difference, $\mathbf{P I}=$ pedigree index, $\mathbf{P M F}=$ preexperimental milk fat, PMP = preexperimental milk protein, $\mathbf{P M Y}=$ preexperimental milk yield, $\mathbf{T D M I}=$ total dry matter intake, $\mathbf{T O M I}=$ total organic matter intake .

\section{INTRODUCTION}

Milk production in Ireland is very dependent on the efficient utilization of grazed grass (Dillon et al., 1995). Grazed grass, when managed properly, is the lowest cost feed (O'Kiely, 1994). Much of the variation in the direct costs of milk production on dairy farms is associated with poor utilization of grazed grass. Therefore, high milk yields must be obtained from a mainly grazed grass-based diet, if costs are to be minimized.

Ulyatt and Waghorn (1993) and Muller and Fales (1998) emphasized that the limitations to cow productivity in pasture-based dairy systems arise from low voluntary intake of herbage and from nutrient levels that differ from those required by lactating cows. The limitation to intake is especially apparent in early lactation, when cows approach peak lactation and grazed herbage is low in DM and often has high CP content. Milk production responses to concentrate supplementation at pasture depend mainly on grass supply and quality, season of year, stage of lactation, and level and type of supplementation (Leaver et al., 1968; Journet 
and Demarquilly, 1979; Stakelum et al., 1988). The latter reviews quoted average responses of between 0.4 and $0.5 \mathrm{~kg}$ of milk per kilogram of concentrate DM. Milk yield responses were generally much less than would be expected because of substitution of concentrate for grazed grass. However, a number of more recent studies have shown higher responses with higher yielding cows (Bargo et al., 2000; Delaby et al., 2001). Since the mid-1980s, the rate of genetic improvement for milk production in Irish dairy herds has increased rapidly through the importation of North American and European Holstein-Friesian genetics. The objective of the present study was to quantify the effect on nutrient intake and utilization, of increasing early and midlactation concentrate supplementation of first-, second-, and third-lactation Holstein-Friesian dairy cows of medium and high genetic merit.

\section{MATERIALS AND METHODS}

The present study was part of a study that examined the performance of two genetic merit dairy cow groups on three grass-based milk production systems over 3 yr (Kennedy et al., 2002).

\section{Animal Groups}

Two genetic groups, containing 48 cows each, were used in 1998 (yr 1). The genotypes were selected from two groups of 60 animals each. All cows were in their first lactation in yr 1. First-lactation cows of similar genetic merit replaced cows culled at the end of lactation in 1998 (18) and in 1999 (12). Cows not in calf at the end of the 13-wk breeding season accounted for $90 \%$ of cows culled in each of the 2 yr. Other diseases such as digestive disorders, mastitis, and lameness accounted for the remaining $10 \%$ of cows culled. The resulting dataset contained 96 first-lactation animals in yr 1, 78 second-lactation and 18 first-lactation animals in 1999 (yr 2) and 72 third-lactation, 12 second-lactation, and 12 first-lactation animals in 2000 (yr 3). Sixtysix animals had records for all three lactations on the same feeding system.

The high merit (HM) cows were selected based on their superior pedigree index (PI) for milk production, while the medium merit (MM) cows were selected on their lesser pedigree index for milk production. Mean PI (and SD) for the HM group were $+276 \mathrm{~kg}$ of milk (100), $+8.9 \mathrm{~kg}$ of fat (4.75), $+9.7 \mathrm{~kg}$ of protein $(3.19),-0.03$ $\mathrm{g}$ of fat $/ \mathrm{kg}(0.086)$ and $+0.01 \mathrm{~g}$ of protein $/ \mathrm{kg}(0.035)$, and the corresponding values for the MM group were +81 $\mathrm{kg}$ of milk (95), $+3.8 \mathrm{~kg}$ of fat (4.95), $+4.3 \mathrm{~kg}$ of protein (2.59), $+0.013 \mathrm{~kg}$ of fat $/ \mathrm{kg}(0.099)$, and +0.031 of protein/ $\mathrm{kg}$ (0.036). The PI for each cow was calculated as 0.50 $\times$ sire predicted difference $(\mathbf{P D})+0.25 \times$ maternal grand sire PD. The PD of the sires and maternal grand-sires were those from the August 2001 international evaluations of the Animal Center, Uppsala, Sweden using the MACE (multiple-trait across-country evaluation) technique, with no Moorepark records included. In 2001, the sires of the cows in both the HM and MM groups had at least 75 daughters in at least 70 Irish herds contributing to these evaluations with a sire reliability of greater than $90 \%$. The average proportion of Holstein Friesian genes in the HM and MM cows were 75 and $65 \%$, respectively; the remaining genes were Friesian. All animals were on a similar feeding system from calving (mid-January) until mid-April in yr 1, when cows were on average 71 DIM. This consisted of ad libitum grass silage while indoors, ad libitum grass silage by night plus grass by day from early February onwards and grass by day and night from mid-March onwards. Concentrate supplementation was $6 \mathrm{~kg} / \mathrm{cow}$ per day in two equal feeds. In mid-April, cows were grouped into blocks of three within each genetic group, on the basis of calving date and milk yield, and randomly assigned to one of three levels of concentrate feeding. Mean preexperimental milk yield (PMY) and (SD) values were $28.5 \mathrm{~kg}$ of milk (2.17) and $0.9 \mathrm{~kg}$ of protein (0.07) for the HM group, and were $23.8 \mathrm{~kg}$ of milk (3.10), and $0.8 \mathrm{~kg}$ of protein (0.07) for MM group.

Over the total lactation in yr 1, 2, and $3 ; 436,348$, and $345 \mathrm{~kg}$ of concentrate/cow per year, as fed, were offered in the low concentrate feeding system (LC); 806, 781 , and $844 \mathrm{~kg}$ in the medium concentrate feeding system (MC); and 1422, 1558, and $1641 \mathrm{~kg}$ in the high concentrate feeding system $(\mathbf{H C})$, respectively. The MC was the industry norm for seasonal spring calving herds in Ireland (Buckley et al., 2000). No concentrate supplementation occurred in July, August, and September, because grass supply is normally adequate and cows are a later stage in lactation. Supplementation is reintroduced in October, because of decreasing grass supply and reduction in forage intake, the lower DM content, increasing proportion of wastage, fouling, and reduced grazing time. The concentrate supplementation strategy is outlined in Table 1. Table 2 shows the chemical composition of the concentrate offered to the cows during each measurement period. The ingredient content of the concentrate (kg/tonne, as fed) was as follows: barley 250 , corn gluten 250 , beet pulp 250 , soybean meal 100, rapeseed meal 100, tallow 10 , and mineral plus vitamins 40 .

\section{Grass-Based Feeding System}

A permanent grassland site was used consisting of a sward with almost $100 \%$ perennial ryegrass (Lolium 
Table 1. Concentrate feeding strategy (kg/cow per day).

\begin{tabular}{llllll}
\hline $\begin{array}{l}\text { Feeding } \\
\text { system }^{1}\end{array}$ & $\begin{array}{l}\text { Calving } \\
\text { to turn out }^{2}\end{array}$ & $\begin{array}{l}\text { Early March } \\
\text { to late } \\
\text { April }^{2}\end{array}$ & $\begin{array}{l}\text { 1st May to } \\
\text { late June }\end{array}$ & $\begin{array}{l}\text { July 1 to } \\
\text { early Oct. }\end{array}$ & $\begin{array}{l}\text { Early Oct } \\
\text { to end of } \\
\text { lactation }\end{array}$ \\
\hline LC & 5 & $3-4$ & 0 & 0 & 0 \\
MC & 7.5 & $4-5$ & 3 & 0 & 2 \\
HC & 10 & $6-7$ & 6 & 4 & 4 \\
\hline
\end{tabular}

${ }^{1} \mathrm{LC}=$ Low concentrate feeding level; $\mathrm{MC}=$ Medium concentrate feeding level $; \mathrm{HC}=$ High concentrate feeding level.

${ }^{2}$ Strategy for yr 2 and 3 only (yr 1 = all cows on $6 \mathrm{~kg} / \mathrm{cow}$ per day during this period).

${ }^{3} 0.4-\mathrm{kg} / \mathrm{cow}$ per day of a high calcined magnesium supplement was fed to LC group.

perenne). Each feeding system had its own farmlet consisting of 18 paddocks of (on average) 0.59 ha. The grazing season extended from late February until late November each year. Grass growth in Ireland is highly seasonal, with little or no growth in December and January, and very rapid growth rates in May and June. At stocking rates of 2.5 to 3.0 cows/ha, grass growth rates are generally adequate to feed cows on pasture only from late April to the end of September. Cows were housed full time in December, January and in the first half of February. The breeding season was confined to 13 wk each year. It started in late April and ended in late July. Therefore, most of the cows calved from February to April, with the aim of the system to allow grazed grass to make a large contribution to the total diet during lactation (Dillon et al., 1995).

The cows were offered grass silage ad libitum during the winter indoor period before calving. Postcalving and before turnout to pasture (late-February), all cows were offered grass silage ad libitum and the level of concentrate specified by the feeding system. Postturnout animals were grazed on a rotational management system (Dillon et al., 1995). Pregrazing yields (> $4 \mathrm{~cm}$ ) were maintained at between 1800 and $2100 \mathrm{~kg}$ of DM/ha. A flexible approach to pasture allocation was adopted, with the aim of providing a postgrazing height of 6 to
$8 \mathrm{~cm}$ for all three feeding levels. Pasture allowances (> $4 \mathrm{~cm}$ ) (SD) on average were 23.6 (1.81), 22.3 (2.30), and $20.0(2.32) \mathrm{kg}$ of $\mathrm{DM} / \mathrm{cow}$ per day for the LC, MC, and HC feeding systems respectively during measurement period 1 (MP1). The corresponding pasture allowances were 24.9 (1.21), 24.6 (2.42), and 23.6 (1.49) $\mathrm{kg}$ of DM/ cow per day in measurement period 2 (MP2) for the $\mathrm{LC}, \mathrm{MC}$, and $\mathrm{HC}$ feeding systems, respectively. This was facilitated through weekly monitoring of farmlet grass cover (O'Donovan, 2000).

All concentrate feeding was offered in individual stalls in the milking parlor in two equal feeds each day, except before turnout to pasture, when concentrate was offered in three equal feeds to the HC cows. Cows were milked twice daily at 0700 and $1600 \mathrm{~h}$ over the $3 \mathrm{yr}$ of the study. First-lactation cows were given a 10 -wk dry period; 8 wk was considered adequate in subsequent lactations.

\section{Animal Measurements}

Individual intakes of all cows were estimated on two occasions while at pasture. MP1 was in mid-June in yr 1 and in mid-May in yr 2 and 3; MP2 was in early September in the 3 yr. The intake estimates in MP1 correspond on average to d 138, 97, and 87 of lactation

Table 2. Chemical composition of concentrate offered.

\begin{tabular}{|c|c|c|c|c|c|c|}
\hline \multirow{2}{*}{$\begin{array}{l}\text { Composition } \\
\text { (g/kg DM) }^{3}\end{array}$} & \multicolumn{2}{|c|}{ Year 1} & \multicolumn{2}{|c|}{ Year 2} & \multicolumn{2}{|c|}{ Year 3} \\
\hline & $\mathrm{A}^{1}$ & $\mathrm{~B}^{2}$ & $\mathrm{~A}^{1}$ & $\mathrm{~B}^{2}$ & $\mathrm{~A}^{1}$ & $\mathrm{~B}^{2}$ \\
\hline DM & 910.3 & 909.9 & 914.6 & 953.4 & 916.0 & 911.7 \\
\hline $\mathrm{CP}$ & 211.0 & 104.1 & 211.5 & 105.9 & 201.9 & 103.1 \\
\hline $\mathrm{CF}$ & 89.3 & 100.0 & 90.3 & 81.0 & 94.4 & 150.9 \\
\hline $\mathrm{NDF}$ & 282.1 & 289.8 & 298.1 & 276.0 & 285.0 & 276.3 \\
\hline Oil & 41.2 & 41.7 & 40.6 & 41.0 & 39.8 & 40.3 \\
\hline NCGD & 831 & 841 & 836 & 821 & 825 & 831 \\
\hline Ash & 95.5 & 242.0 & 91.4 & 245.1 & 100.7 & 250.3 \\
\hline
\end{tabular}

\footnotetext{
${ }^{1} \mathrm{~A}=$ Concentrate fed to $\mathrm{MC}$ and $\mathrm{HC}$ groups during measurement period 1 , and to the $\mathrm{HC}$ system during measurement period 2 .

${ }^{2} \mathrm{~B}=$ Concentrate fed to LC group during measurement period 1.

${ }^{3} \mathrm{CP}=$ Crude protein, $\mathrm{CF}=$ crude fiber, NCGD = neutral cellulose grammonase digestibility.
} 
for yr 1 to 3 , respectively. In MP2 the intake estimates correspond to d 187, 209, and 206 of lactation, respectively. Individual animal intakes were estimated using the n-alkane technique (Mayes et al., 1986) as modified by Dillon and Stakelum (1989). In yr 1 and 2, each cow was dosed $8 \mathrm{~d}$ before fecal collection with slow release CAPTEC n-alkane CRC n-dotriacontane (C32), assay 198, wt/wt, and linear density $145.2 \mathrm{mg} / \mathrm{mm}$ (CAPTEC), (NZ Ltd., Auckland). After the 8-d equilibration period, fecal grab samples were collected twice daily, after morning and evening milkings, in the following $6 \mathrm{~d}$. In yr 3, the cows were dosed twice daily (after milking) for a 12-d period with paper filters or bungs (Carl Roth, $\mathrm{GmbH}$ and Co. KG, Karlesruhe, Germany) containing approximately $500 \mathrm{mg}$ of C32 each. Fecal grab samples were collected twice daily from each cow (after milking) in the last $6 \mathrm{~d}$. The fecal samples from each cow for each 6-d period were bulked for analysis. Herbage samples were collected manually to represent herbage grazed (following close observation of the grazing animal) after both the morning and evening milking on $d$ 6 to 11 of each measurement period. The ratio of herbage C33 (tritriacontane) to dosed C32 was used to estimate intake. The dietary DM and OM digestibility coefficients were estimated from the concentration of the C35 (pentatriacontane) n-alkane (Dove and Mayes, 1991), assuming a fecal recovery of 0.90 (Dillon, 1993). The n-alkane concentration of the dosed pellets, feces, herbage, and concentrate were determined as described by Dillon (1993). Estimates of daily herbage intake were calculated as follows:

$$
\begin{aligned}
& \text { Daily herbage intake }(\mathrm{kg} D M)= \\
& \frac{\mathrm{F}_{\mathrm{i}} / \mathrm{F}_{\mathrm{j}} \times\left(\mathrm{D}_{\mathrm{j}}+\mathrm{I}_{\mathrm{c}} \times \mathrm{C}_{\mathrm{j}}\right)-\mathrm{I}_{\mathrm{c}} \times \mathrm{C}_{\mathrm{i}}}{\mathrm{H}_{\mathrm{i}}-\left(\mathrm{F}_{\mathrm{i}} / \mathrm{F}_{\mathrm{j}} \times \mathrm{H}_{\mathrm{j}}\right)}
\end{aligned}
$$

where $\mathrm{F}_{\mathrm{i}}, \mathrm{C}_{\mathrm{i}}$, and $\mathrm{H}_{\mathrm{i}}$ are the concentrations $(\mathrm{mg} / \mathrm{kg}$ of $\mathrm{DM}$ ) of the natural odd-chain n-alkanes in feces, concentrate, and pasture, respectively, $\mathrm{F}_{\mathrm{j}}, \mathrm{C}_{\mathrm{j}}$, and $\mathrm{H}_{\mathrm{j}}$ are the concentrations $(\mathrm{mg} / \mathrm{kg}$ of $\mathrm{DM})$ of the even-chain n-alkane in feces, concentrate and pasture, respectively, $D_{i}$ is the dose rate $(\mathrm{mg} / \mathrm{d})$ of the even-chain $\mathrm{n}$-alkane, and $\mathrm{I}_{\mathrm{c}}$ is the daily concentrate intake $(\mathrm{kg} \mathrm{DM} / \mathrm{d})$. Estimates of diet DMD were calculated also from the ratio of feed and fecal concentrations of the natural odd-chain nalkane C35 as follows:

$$
\mathrm{DMD}=1-\left(\mathrm{H}_{\mathrm{i}} \times \mathrm{R}_{\mathrm{i}}\right) / \mathrm{F}_{\mathrm{i}},
$$

where $\mathrm{H}_{\mathrm{i}}$ and $\mathrm{F}_{\mathrm{i}}$ are the concentrations ( $\mathrm{mg} / \mathrm{kg}$ of $\mathrm{DM}$ ) of the natural C35 alkane in feed and feces, respectively. The recovery of C35 in the feces was assumed to be
0.90 , based on the results reported for dairy cows fed pasture (Dillon, 1993).

During MP1, the LC, MC, and HC cows were offered $0.0,3.0$, and $6.0 \mathrm{~kg}$ of concentrate as fed daily, respectively. During MP1, the LC group received $0.5 \mathrm{~kg}$ of a high calcined magnesite supplement to prevent grass tetany. During MP2, HC cows were offered $4.0 \mathrm{~kg}$ of concentrate as fed daily; $\mathrm{LC}$ and $\mathrm{MC}$ cows were on grass only. Individual milk yields were recorded on 5 consecutive days per week (Monday to Friday) in the $3 \mathrm{yr}$. Milk fat, protein, and lactose concentrations were determined in successive morning and evening milk samples once each week using a Fos-let instrument (AS/N Foss Electric; Hillerød, Denmark). Milks were analyzed for total protein (International Dairy Federation, 1993). BW was recorded weekly and BCS (Lowman et al., 1976) once every 3 to 4 wk.

\section{Sward Measurements}

Pregrazing herbage yield (above the 4-cm horizon) was determined in each grazing paddock based on four strips of grass (0.95-m wide; 4.5 to $5.5-\mathrm{m}$ long) cut with an Agri mower. The grass from each strip was weighed and sampled, and a sub-sample was dried overnight at $90^{\circ} \mathrm{C}$ for $\mathrm{DM}$ determination. The remaining herbage from the four samples from each paddock were bulked and a subsample taken. This subsample (approximately $100 \mathrm{~g}$ ) was freeze-dried and used for chemical analyses.

The chemical analyses were in vitro OM digestibility (OMD) (Morgan et al., 1989), DM digestibility (DMD), CP based on Kjeldahl N, modified acid detergent fiber (MADF) (Clancy and Wilson, 1966) and NDF (Van Soest, 1966). A total of 30 pre- and postgrazing sward surface heights (Hutchings, 1991) were recorded in each paddock immediately prior to grazing and immediately post-grazing.

\section{STATISTICAL ANALYSIS}

The animal production data for MP1 and MP2 in the 3 yr $(3 \times 96$ cows), were analyzed as a $2 \times 3$ factorial experiment, arranged in a split plot design, using the general linear statistical procedures of SAS (1991). The model used was as follows:

$$
\begin{aligned}
\mathrm{Y}_{i j k l m}=\mathrm{G}_{i} & +\mathrm{L}_{j}+\left(\mathrm{G}^{*} \mathrm{~L}\right)_{i j}+\mathrm{B}_{k}\left(\mathrm{G}_{i}^{*} \mathrm{~L}_{j}\right)+\mathrm{F}_{l}+\left(\mathrm{G}^{*} \mathrm{~F}\right)_{i l} \\
& +\left(\mathrm{L}^{*} \mathrm{~F}\right)_{j i}+\left(\mathrm{G}^{*} \mathrm{~L}^{*} \mathrm{~F}\right)_{i j k}+\mathrm{e}_{i j k l m},
\end{aligned}
$$

where:

$$
\begin{aligned}
\mathrm{Y}_{i j k l m} & =\text { observation for each trait on animal } i, \\
\mathrm{G}_{i} & =\text { genetic group }(i=1,2), \\
\mathrm{L}_{j} & =\text { lactation number }(j=1,2,3),
\end{aligned}
$$




$$
\begin{aligned}
\mathrm{B}_{k}\left(\mathrm{G}_{i} * \mathrm{~L}_{j}\right)= & \text { effect of block } j \text { within genetic group } i \text { by } \\
& \text { lactation number } j \text { interaction, } \quad(k= \\
& 1,2,3, \ldots 16), \\
\mathrm{F}_{l}= & \text { concentrate feeding level }(l=1,2,3), \\
\mathrm{e}_{i j k l m}= & \text { residual error term. }
\end{aligned}
$$

Genotype, lactation number, and genotype $\times$ lactation number were tested for significance using block (genotype $\times$ lactation number) as the error term; feed, genotype $\times$ feed, lactation number $\times$ feed, and genotype $\times$ lactation number $\times$ feed were tested using the residual as the error term.

In MP1, linear and quadratic orthogonal polynomial contrasts, embedded in the treatment structure, were used to test for linear and curvilinear trends with concentrate supplementation level (Snedecor and Cochran, 1980). In MP2, concentrate intake (CI) was similar for both LC and MC. Orthogonal contrasts were used to test the effect of the concentrate level of supplementation $((\mathrm{LC}+\mathrm{MC}) / 2$ vs. $\mathrm{HC})$ and the carryover effect of $\mathrm{MC}$ supplementation in early lactation (MC vs. LC).

An overall multiple regression analysis was carried out on data for the 66 cows, which remained on the study (in the same feeding systems), for the $3 \mathrm{yr}$ to examine the effects on milk production due to PMY, grass DM intake (GDMI), CI, DIM, and lactation number (LN). The effects on GDMI of PMY, CI, pre-experimental BW (PBW) and LN were also analyzed by multiple regression analysis.

\section{RESULTS}

\section{Sward Measurements}

The herbage allocated to each of the concentrate feeding levels had similar pregrazing yields and heights, and all groups grazed to a similar intensity in each measurement period (Table 3). The chemical compositions of the herbage selected were similar for all three concentrate-feeding levels; the herbage selected was of high quality, as indicated by the high OMD (organic matter digestibility) and $\mathrm{CP}$ values, and the low MADF (modified acid detergent fiber) values (Table 4).

\section{Animal Measurements}

Early lactation. Table 5 shows the effect of genotype, concentrate feeding level, and the genotype $\times$ concentrate feeding level interaction on milk production, intake and BW in MP1. The HM cows produced significantly $(P<0.001)$ higher milk yield $(+4.4 \mathrm{~kg} / \mathrm{d})$, SCM $(+3.0 \mathrm{~kg} / \mathrm{d})$ (Tyrell and Reid, 1965), fat $(+0.16 \mathrm{~kg} / \mathrm{d})$, protein $(+0.13 \mathrm{~kg} / \mathrm{d})$, and lactose $(+0.19 \mathrm{~kg} / \mathrm{d})$ yields than the MM cows. The MM cows produced milk with significantly higher fat $(+2.0 \mathrm{~g} / \mathrm{kg} ; P<0.01)$, protein $(+0.8$ $\mathrm{g} / \mathrm{kg} ; P<0.05)$ and lactose $(+0.7 \mathrm{~g} / \mathrm{kg} ; P<0.001)$ concentrations than the HM cows. The HM cows had significantly $(P<0.001)$ higher grass OM intake (GOMI) $(+1.01 \mathrm{~kg} / \mathrm{d})$, total OM intake (TOMI) $+0.91 \mathrm{~kg} / \mathrm{d})$, grass DM intake (GDMI) $(+1.04 \mathrm{~kg} / \mathrm{d})$ and total DM intake (TDMI) $(0.92 \mathrm{~kg} / \mathrm{d})$ than the MM cows. Genotype had no significant effect on diet digestibility coefficients or BW. However, DMI per $100 \mathrm{~kg}$ of BW (results not shown), was higher $(P<0.01)$ for the HM than the MM cows (3.29 vs. $3.14 \%)$. Milk, protein, and lactose yields increased linearly with increasing concentrate, and the genotype responses did not differ significantly. The responses of fat and SCM yields to increasing level of concentrate depended on genotype. The response was linear for the HM cows, and it was curvilinear for the MM cows. The effect of concentrate level on milk fat concentration depended on genotype; the response was curvilinear for the MM genotype, and there was no effect with the HM genotype. Milk protein concentration increased linearly with increasing concentrate level; the response did not differ significantly between genotypes. The increase in milk lactose concentration with level of concentrate was significantly greater with the MM than with the HM genotype. The responses of GOMI, GDMI, OMD, DMD, and BW to concentrate level were linear and negative and did not differ significantly between genotypes. Similarly, the responses of TOMI and TDMI to concentrate level were linear but were positive and did not differ significantly between genotypes. Parity had a significant $(P<0.001)$ effect on milk production and TDMI (Figure 1). The average daily milk yields were $23.6,31.4$, and $34.4 \mathrm{~kg} / \mathrm{cow}$, while the average TDMI were $14.9,17.7$ and $20.9 \mathrm{~kg} / \mathrm{cow}$ per day for LN 1, 2 and 3 respectively.

Table 6 shows multiple regression equations predicting milk production and GDMI from a combination of independent variables associated with the 66 cows which remained on the study for the $3 \mathrm{yr}$. The partial regression coefficient of PMY, CI, GDMI, DIM, and LN on milk, protein, and fat yields were significant. The proportion of the variation explained by the equations ranged from $82 \%(\mathrm{RSD}=0.082)$ for protein yield to $71 \%(\mathrm{RSD}=0.132)$ for fat yield. The partial regression coefficient relating daily milk yield to an increase of 1 $\mathrm{kg}$ of PMY was 0.676 . The values were 0.688 and 0.305 for preexperimental milk protein (PMP) and preexperimental milk fat (PMF), respectively. The partial regression coefficients relating daily milk yield to an increase of $1 \mathrm{~kg}$ of CI was $+1.10 \mathrm{~kg}$ of milk, $+0.038 \mathrm{~kg}$ of protein and $+0.032 \mathrm{~kg}$ of fat. Similarly, for each kilogram of GDMI, milk yield increased by 0.335 . Table 6 also shows the equation predicting GDMI from independent variables PMY, PBW, CI, DIM, and LN. The equation accounted for $68 \%(\mathrm{RSD}=1.865)$ of the variation in the 
Table 3. Pre- and postgrazing heights $(\mathrm{cm})$ and pregrazing herbage yields $(\mathrm{kg} \mathrm{DM} / \mathrm{ha})$ of the pastures grazed by the cows during each intake measurement period (MP).

\begin{tabular}{|c|c|c|c|c|c|c|c|}
\hline \multirow[b]{2}{*}{ Year } & \multirow[b]{2}{*}{$\mathrm{MP}^{1}$} & \multirow[b]{2}{*}{ Item $^{2}$} & \multicolumn{4}{|c|}{ Concentrate feeding levels ${ }^{3}$} & \multirow{2}{*}{$\begin{array}{l}\text { Prob }>\mathrm{F}^{4} \\
\text { Feed }\end{array}$} \\
\hline & & & $\mathrm{LC}$ & $\mathrm{MC}$ & $\mathrm{HC}$ & $\mathrm{SE}$ & \\
\hline 1 & 1 & $\begin{array}{l}\text { Pre-GSSH } \\
\text { Post-GSSH } \\
\text { Pre-GHY }\end{array}$ & $\begin{array}{c}\cdots \\
6.88 \\
1886\end{array}$ & $\begin{array}{l}\cdots \\
2188\end{array}$ & $\begin{array}{c}\cdots \\
1960\end{array}$ & $\begin{array}{c}\cdots \\
0.302 \\
134.3\end{array}$ & $\begin{array}{l}\text { NS } \\
\text { NS }\end{array}$ \\
\hline 1 & 2 & $\begin{array}{l}\text { Pre-GSSH } \\
\text { Post-GSSH } \\
\text { Pre-GHY }\end{array}$ & $\begin{array}{l}\cdots \\
2192\end{array}$ & $\begin{array}{l}\cdots \\
2192\end{array}$ & $\begin{array}{l}\cdots \\
2228\end{array}$ & $\begin{array}{l}\cdots \\
0.260 \\
122.3\end{array}$ & $\begin{array}{l}\ddot{\mathrm{NS}} \\
\mathrm{NS}\end{array}$ \\
\hline 2 & 1 & $\begin{array}{l}\text { Pre-GSSH } \\
\text { Post-GSSH } \\
\text { Pre-GHY }\end{array}$ & $\begin{array}{r}25.88 \\
6.94 \\
2365\end{array}$ & $\begin{array}{r}25.62 \\
7.04 \\
2440\end{array}$ & $\begin{array}{r}24.84 \\
6.97 \\
2167\end{array}$ & $\begin{array}{r}0.993 \\
0.326 \\
100.9\end{array}$ & $\begin{array}{l}\text { NS } \\
\text { NS } \\
\text { NS }\end{array}$ \\
\hline 2 & 2 & $\begin{array}{l}\text { Pre-GSSH } \\
\text { Post-GSSH } \\
\text { Pre-GHY }\end{array}$ & $\begin{array}{r}21.90 \\
6.57 \\
2114\end{array}$ & $\begin{array}{r}25.00 \\
6.88 \\
2530\end{array}$ & $\begin{array}{r}24.53 \\
7.08 \\
2610\end{array}$ & $\begin{array}{r}1.193 \\
0.383 \\
114.4\end{array}$ & $\begin{array}{l}\text { NS } \\
\text { NS } \\
\text { NS }\end{array}$ \\
\hline 3 & 1 & $\begin{array}{l}\text { Pre-GSSH } \\
\text { Post-GSSH } \\
\text { Pre-GHY }\end{array}$ & $\begin{array}{r}23.30 \\
6.82 \\
2334\end{array}$ & $\begin{array}{r}24.20 \\
6.70 \\
2227\end{array}$ & $\begin{array}{r}21.30 \\
6.58 \\
2171\end{array}$ & $\begin{array}{r}1.103 \\
0.239 \\
111.9\end{array}$ & $\begin{array}{l}\text { NS } \\
\text { NS } \\
\text { NS }\end{array}$ \\
\hline 3 & 2 & $\begin{array}{l}\text { Pre-GSSH } \\
\text { Post-GSSH } \\
\text { Pre-GHY }\end{array}$ & $\begin{array}{r}20.54 \\
8.00 \\
1919\end{array}$ & $\begin{array}{r}20.71 \\
7.63 \\
1969\end{array}$ & $\begin{array}{r}22.22 \\
7.14 \\
2080\end{array}$ & $\begin{array}{l}0.613 \\
0.208 \\
97.3\end{array}$ & $\begin{array}{l}\text { NS } \\
\text { NS } \\
\text { NS }\end{array}$ \\
\hline
\end{tabular}

\footnotetext{
${ }^{1} \mathrm{MP}=$ Measurement period; 1 = early lactation yr 1, 2, and 3; 2 = late lactation yr 1, 2, and 3.

${ }^{2}$ Pre-GSSH = Pregrazing sward surface height, Post-GSSH = postgrazing sward surface height, and Pre$\mathrm{GHY}=$ pregrazing herbage yield.

${ }^{3} \mathrm{LC}=$ Low concentrate feeding level, $\mathrm{MC}=$ medium concentrate feeding level, $\mathrm{HC}=$ high concentrate feeding level.

${ }^{4}$ Feed $=$ Effect of concentrate feeding level.
}

GDMI. The partial regression coefficients relating daily GDMI to an increase in $1 \mathrm{~kg}$ of PMY, PBW and CI were $0.123,0.006$ and -0.54 , respectively.

Late lactation. Table 7 shows the effect of genotype, concentrate feeding level, and the interaction concentrate feeding level $\times$ genotype on milk production, intake, and BW in MP2. As in early lactation, the HM cows produced significantly $(P<0.001)$ higher milk
$(+3.2 \mathrm{~kg} / \mathrm{d}), \mathrm{SCM}(+2.2 \mathrm{~kg} / \mathrm{d})$, fat $(+0.07 \mathrm{~kg} / \mathrm{d}$, protein $(+0.09 \mathrm{~kg} / \mathrm{d})$ and lactose $(+0.12 \mathrm{~kg} / \mathrm{d})$ yields than the MM cows. The MM cows produced milk of significantly higher fat $(+1.5 \mathrm{~g} / \mathrm{kg} ; P<0.01)$, protein $(+0.6 \mathrm{~g} / \mathrm{kg} ; P<$ $0.05)$ and lactose $(+0.7 \mathrm{~g} / \mathrm{kg} ; P<0.001)$ concentration than the HM cows. The HM cows had significantly $(P$ $<0.01)$ higher GOMI $(+0.92 \mathrm{~kg} / \mathrm{d})$, TOMI $(+0.91 \mathrm{~kg} / \mathrm{d})$, GDMI $(+1.01 \mathrm{~kg} / \mathrm{d})$, and TDMI $(+0.99 \mathrm{~kg} / \mathrm{d})$. Genotype

Table 4. Chemical composition of herbage representing that selected by the cows during measurement periods in each year (SD).

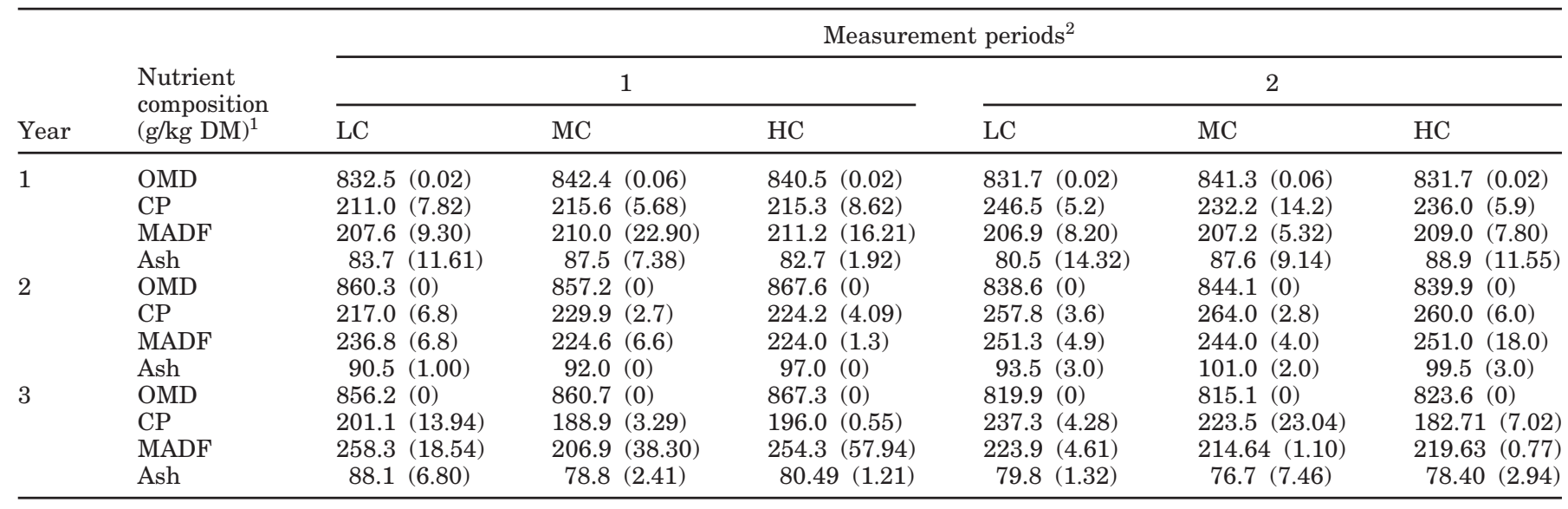

${ }^{1} \mathrm{OMD}=$ Organic matter digestibility, $\mathrm{MADF}=$ modified acid detergent fiber.

${ }^{2} 1$ = early-lactation measurement period, $2=$ late-lactation measurement period, LC $=$ low concentrate feeding level, $\mathrm{MC}=$ medium concentrate feeding level, $\mathrm{HC}=$ high concentrate feeding level. 
Table 5. Effect of genotype and feeding system on cow performance in early lactation $(\mathrm{n}=288)$.

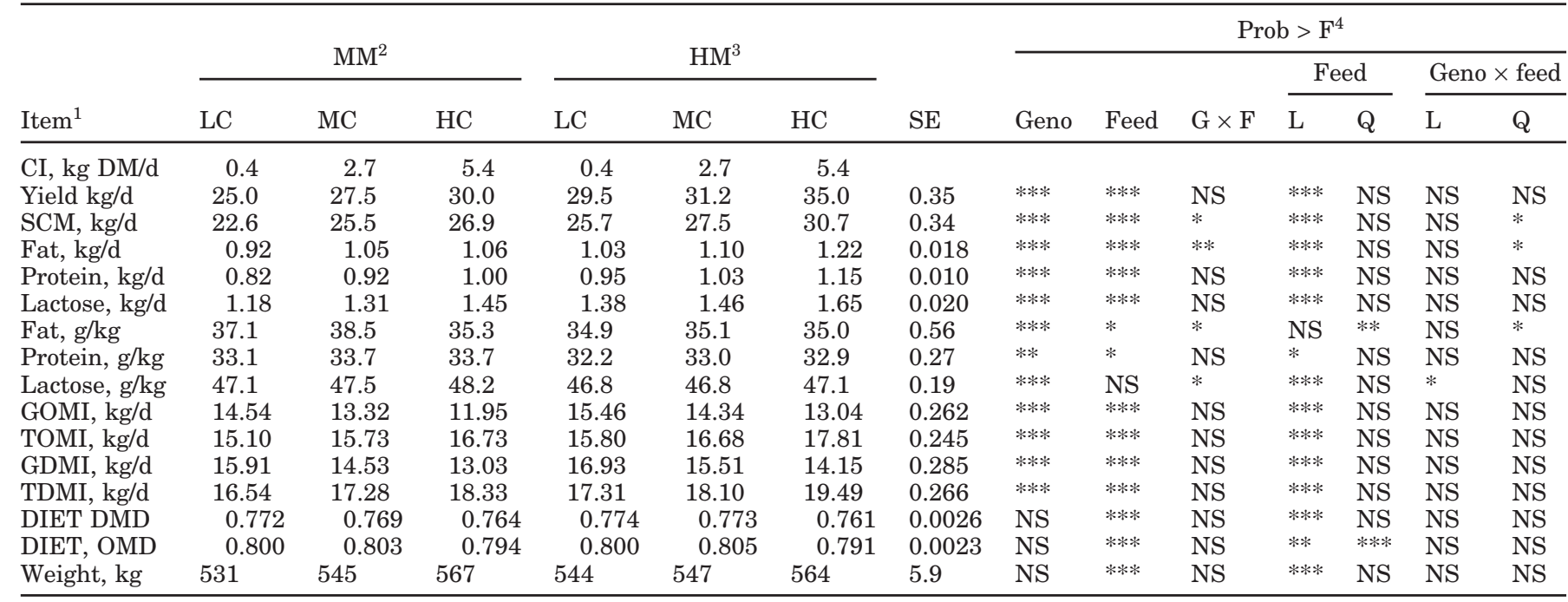

${ }^{1} \mathrm{CI}=$ Concentrate intake, GOMI $=$ grass $\mathrm{OM}$ intake, $\mathrm{TOMI}=$ total OM intake, GDMI $=$ grass DM intake, TDMI = total DM intake, DIET $\mathrm{DMD}=\mathrm{DM}$ digestibility, DIET OMD $=\mathrm{OM}$ digestibility $(\mathrm{g}$ of digestible $\mathrm{DM} / \mathrm{kg}$ of DM).

${ }^{2} \mathrm{MM}=$ Medium merit, $\mathrm{LC}=$ low concentrate feeding level, $\mathrm{MC}=$ medium concentrate feeding level, $\mathrm{HC}=$ high concentrate feeding level. ${ }^{3} \mathrm{HM}=$ High merit.

${ }^{4}$ Geno = Effect of genotype; Feed = effect of feeding system; $\mathrm{G} \times \mathrm{F}=$ effect of interaction between genotype and feeding system; $\mathrm{L}=$ linear; $\mathrm{Q}=$ quadratic.

$* P \leq 0.05$.

$* * P \leq 0.01$.

$* * * P \leq 0.001$

had no significant effect on diet digestibility coefficients or BW. Similar to MP1, the DMI per $100 \mathrm{~kg}$ of BW was higher $(P<0.01)$ for the HM than the MM cows $(3.24$ vs. $3.07 \%)$.

There was no significant difference between the LC and the MC feeding levels for any animal production parameters measured except milk fat concentration, which was significantly higher $(P<0.01)$ in the MC group. However, the HC cows produced significantly $(P$

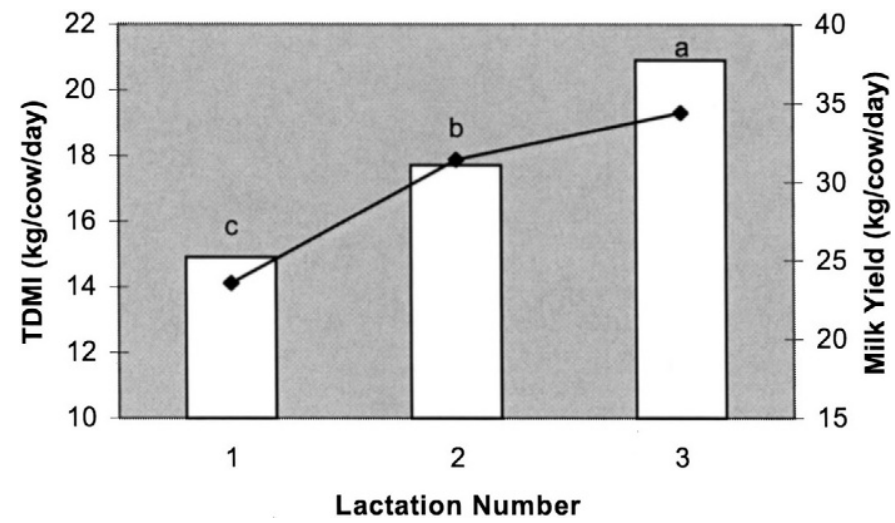

Figure 1. The effect of lactation number on milk production ) and total DM intake ( $\square$ ) in early lactation (a, b, c, $P \leq 0.001$ ).
$<0.001)$ higher milk $(+2.8 \mathrm{~kg} / \mathrm{d})$, SCM $(+2.6 \mathrm{~kg} / \mathrm{d})$, fat $(+0.09 \mathrm{~kg} / \mathrm{d})$, protein $(+0.15 \mathrm{~kg} / \mathrm{d})$, and lactose $(+0.14 \mathrm{~kg} /$ d) yields than the LC cows. The HC cows also produced milk with significantly $(P<0.05)$ higher concentration of protein $(+0.65 \mathrm{~g} / \mathrm{kg})$ and lactose $(+0.35 \mathrm{~g} / \mathrm{kg})$. As in early lactation, the $\mathrm{HC}$ feeding system significantly ( $P$ $<0.001)$ reduced GOMI $(-1.52 \mathrm{~kg} / \mathrm{d})$ and GDMI $(-1.66$ $\mathrm{kg} / \mathrm{d})$ and increased TOMI (+1.56 kg/d $)$ and TDMI $(+1.77$ $\mathrm{kg} / \mathrm{d})$. Body weight was significantly $(P<0.001)$ higher with the HC feeding system $(+32 \mathrm{~kg})$. The dietary digestibility coefficients for the HC cows were significantly higher for DMD $(+0.010 ; P<0.01)$ and OMD $(+0.010 ; P<0.001)$. Similar to MP1, parity had a significant $(P<0.001)$ effect on milk production and TDMI in MP2 (Figure 2). The average daily milk yields were $20.8,22.4$, and $23.2 \mathrm{~kg} / \mathrm{cow}$, while the average TDMI's were $16.5,17.4$, and $19.8 \mathrm{~kg} / \mathrm{cow}$ for $\mathrm{LN} 1,2$, and 3, respectively. Table 8 shows equations predicting milk, protein, and fat yields from independent variables PMY, CI, GDMI, DIM and LN. The proportion of the variation explained by the equations ranged from $72 \%$ $(\mathrm{RSD}=0.069)$ for protein yield to $41 \%(\mathrm{RSD}=0.105)$ for fat yield. The partial coefficient relating daily milk yield to an increase of $1 \mathrm{~kg}$ of PMY was 0.440 . The values were 0.428 and 0.251 for PMP and PMF, respectively. The partial regression coefficients relating daily 
Table 6. A selection of models for predicting milk production and grass DMI (GDMI) from a combination of independent variables in measurement period 1 (MP1) $(n=198)$.

\begin{tabular}{|c|c|c|c|c|}
\hline Equations & Milk yield (kg) & Milk protein $(\mathrm{kg})$ & Milk fat (kg) & GDMI (kg) \\
\hline $\operatorname{PMY}(\mathrm{kg} / \mathrm{cow} / \text { day })^{1}$ & $0.676(* * *)$ & & & $0.123(* *)$ \\
\hline PMP (kg/cow/day) & $\ldots$ & 0.688 (***) & $\ldots$ & $\ldots$ \\
\hline PMF (kg/cow/day) & $\ldots$ & $\ldots$ & $0.305(* * *)$ & \\
\hline PBW (kg) & & & & $0.006(\dagger)$ \\
\hline $\mathrm{CI}(\mathrm{kg} \mathrm{DM})^{2}$ & $1.28(* * *)$ & 0.043 (***) & 0.040 (***) & $-0.54(* * *)$ \\
\hline GDMI (kg/cow/day $)^{3}$ & $0.335(* *)$ & 0.0088 (**) & $0.0157(* *)$ & \\
\hline DIM & $-0.072(* * *)$ & -0.0016 (***) & $-0.0029(* * *)$ & $0.019(* *)$ \\
\hline LN 1 & $-3.028(* * *)$ & $-0.103(* * *)$ & -0.109 (***) & $-3.282(* * *)$ \\
\hline LN 2 & $0.469(* * *)$ & $-0.014(* * *)$ & -0.023 (***) & $0.031(* * *)$ \\
\hline LN 3 & $2.558(* * *)$ & 0.089 (***) & $0.085(* * *)$ & $3.251(* * *)$ \\
\hline Intercept & 10.878 & 0.320 & 0.698 & 8.120 \\
\hline $\mathrm{R}^{2}$ & 0.815 & 0.822 & 0.712 & 0.677 \\
\hline $\mathrm{RSD}^{4}$ & 2.753 & 0.082 & 0.132 & 1.865 \\
\hline
\end{tabular}

${ }^{1} \mathrm{PMY}, \mathrm{PMP}, \mathrm{PMF}$, and PBW = Average production figures for weeks 5, 6, 7 and 8 of lactation in 1998, for milk, protein, fat and body-weight.

${ }^{2} \mathrm{CI}=$ Concentrate intake.

${ }^{3} \mathrm{GDMI}=$ Grass dry matter intake.

${ }^{4} \mathrm{RSD}=$ Residual standard deviation.

$\dagger P \leq 0.10$.

$* P \leq 0.05$.

$* * P \leq 0.01$.

$* * * P \leq 0.001$.

milk yield to an increase of $1 \mathrm{~kg}$ of CI was $+0.94 \mathrm{~kg}$ of milk, $+0.037 \mathrm{~kg}$ of protein and $+0.025 \mathrm{~kg}$ of fat. Similarly for each $\mathrm{kg}$ of GDMI, milk yield increased by 0.497 . Table 8 also shows the equation predicting GDMI from independent variables PMY, PBW, CI, DIM, and LN. The equation accounted for $57 \%(\mathrm{RSD}=1.788)$ of the variation in GDMI. The partial regression coefficient relating daily GDMI to an increase in $1-\mathrm{kg}$ of PMY, PBW, and CI were $0.190,0.007$ and -0.444 , respectively.

\section{DISCUSSION}

Cows on each concentrate feeding level grazed separate farmlets; however, they had access to almost iden-

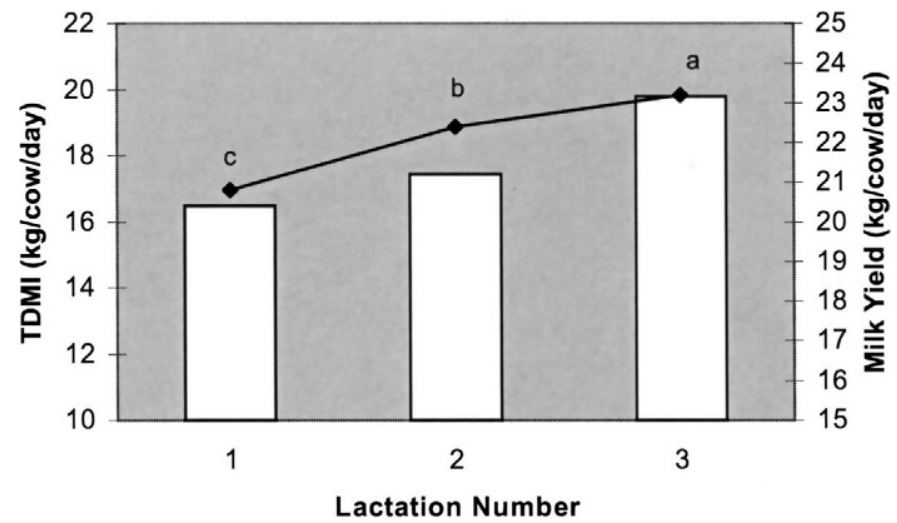

Figure 2. The effect of lactation number on milk production $\checkmark)$ and total DM intake ( $\square$ ) in late lactation (a, b, c, $P \leq 0.001$ ). tical swards and grazed to similar postgrazing residual heights. They also consumed herbage of similar chemical composition. The grazing conditions, as indicated from the chemical composition of the herbage and the residual postgrazing heights, were the optimum for high animal performance (Stakelum and Dillon, 1990).

The higher milk production achieved with the HM cows is similar to that previously reported (Bryant and Trigg, 1981; Veerkamp et al., 1994; Buckley et al., 2000). Other studies comparing HM and MM cows show that increases in milk production were not accompanied by a reduction in the milk fat, protein and lactose contents (Bryant and Trigg, 1981; Grainger et al., 1985; Veerkamp et al., 1994). The milk constituent's reduction in the present study probably reflects the genetic predisposition of the animals to produce milk of differing composition as indicated in their pedigree index. The significantly higher GDMI of the HM cows is similar to that reported previously (Buckley et al., 2000). The selection of cows for higher milk production leads to higher feed intake as a consequence of the genetic correlation between the traits (Van Arendonk et al., 1991). The nonsignificant effect of genotype on OMD and DMD is expected (Holmes, 1988).

The experimental milk yields were a function of PMY (average milk production in lactation wk 5, 6, 7, and 8 of yr 1, when all animals were on the same feeding system), CI, GDMI, DIM, and LN. The response to an increase of $1 \mathrm{~kg}$ of PMY was $0.676 \mathrm{~kg}$ and $0.440 \mathrm{~kg}$ milk daily in MP1 and MP2, respectively. The higher value in MP1 than in MP2 is probably due to the PMY covariable 
Table 7. Effect of genotype and feeding system on cow performance in late lactation $(\mathrm{n}=288)$.

\begin{tabular}{|c|c|c|c|c|c|c|c|c|c|c|c|c|}
\hline \multirow[b]{3}{*}{ Item $^{1}$} & \multirow{2}{*}{\multicolumn{3}{|c|}{$\mathrm{MM}^{2}$}} & \multirow{2}{*}{\multicolumn{3}{|c|}{$\mathrm{HM}^{3}$}} & \multirow[b]{3}{*}{$\mathrm{SE}$} & \multirow[b]{3}{*}{ Geno } & \multirow[b]{3}{*}{ Feed } & \multicolumn{2}{|c|}{ Prob $>F^{4}$} & \\
\hline & & & & & & & & & & \multirow[b]{2}{*}{$\mathrm{G} \times \mathrm{F}$} & \multicolumn{2}{|l|}{ Contrast } \\
\hline & $\mathrm{LC}$ & $\mathrm{MC}$ & $\mathrm{HC}$ & $\mathrm{LC}$ & $\mathrm{MC}$ & $\mathrm{HC}$ & & & & & $(\mathrm{LC}+\mathrm{MC} / 2) \mathrm{v} \mathrm{HC}$ & $\mathrm{LC}$ v MC \\
\hline Yield, kg/d & 19.9 & 19.7 & 22.5 & 22.8 & 22.1 & 25.9 & 0.35 & $* * *$ & $* * *$ & NS & $* * *$ & NS \\
\hline $\mathrm{SCM}, \mathrm{kg} / \mathrm{d}$ & 18.4 & 18.9 & 20.7 & 20.6 & 20.3 & 23.5 & 0.30 & $* * *$ & $* * *$ & NS & $* * *$ & NS \\
\hline Fat, kg/d & 0.77 & 0.81 & 0.84 & 0.85 & 0.84 & 0.95 & 0.020 & $* * *$ & $* * *$ & $*$ & $* * *$ & NS \\
\hline Fat, g/kg & 38.8 & 41.4 & 37.3 & 37.3 & 38.4 & 37.3 & 0.64 & $* *$ & $* *$ & NS & NS & $* *$ \\
\hline Protein, $\mathrm{g} / \mathrm{kg}$ & 35.1 & 36.0 & 35.7 & 34.7 & 34.8 & 35.4 & 0.31 & $*$ & NS & NS & $*$ & NS \\
\hline Lactose, g/kg & 45.8 & 45.4 & 46.6 & 45.3 & 44.9 & 45.3 & 0.20 & $* * *$ & $* *$ & NS & $*$ & NS \\
\hline GOMI, kg/d & 15.11 & 15.25 & 13.93 & 16.44 & 16.03 & 14.58 & 0.249 & $* *$ & $* * *$ & NS & $* * *$ & NS \\
\hline TOMI, kg/d & 15.20 & 15.30 & 17.00 & 16.44 & 16.03 & 17.75 & 0.252 & $* *$ & $* * *$ & NS & $* * *$ & NS \\
\hline GDMI, kg/d & 16.57 & 16.75 & 15.29 & 18.04 & 17.61 & 16.00 & 0.275 & $* *$ & $* * *$ & NS & $* * *$ & NS \\
\hline TDMI, kg/d & 16.70 & 16.80 & 18.73 & 18.04 & 17.61 & 19.55 & 0.277 & $* *$ & $* * *$ & NS & $* * *$ & NS \\
\hline
\end{tabular}

${ }^{1} \mathrm{CI}=$ Concentrate intake, GOMI = grass OM intake, TOMI = total OM intake, GDMI = grass DMI, TDMI = total DMI, DIET DMD = DM digestibility, DIET OMD = OM digestibility ( $\mathrm{g}$ of digestible $\mathrm{DM} / \mathrm{kg}$ of $\mathrm{DM}$ ).

${ }^{2} \mathrm{MM}=$ Medium genetic merit, $\mathrm{LC}=$ low concentrate feeding level, $\mathrm{MC}=$ medium concentrate feeding level, $\mathrm{HC}=$ high concentrate feeding level.

${ }^{3} \mathrm{HM}=$ High genetic merit.

${ }^{4}$ Geno $=$ Effect of genotype; Feed $=$ effect of feeding system; $\mathrm{G} \times \mathrm{F}=$ effect of interaction between genotype and feeding system .

$* P \leq 0.05$.

$* * P \leq 0.01$.

$* * * P \leq 0.001$

measurement time, being closer to MP1 and also earlier in lactation.

The average milk yield response in MP1 of $1.10 \mathrm{~kg}$ of milk per kilogram of concentrate DM intake is higher than that reported previously (Leaver et al., 1968; Journet and Demarquilly, 1979; Stakelum et al., 1987), and this response was linear up to the highest supplementation level. However, more recent studies have shown similar higher milk production responses (Robaina et al., 1998; Bargo et al., 2000; Reis and Combs, 2000; Delaby et al., 2001). Bargo et al. (2000) obtained responses to concentrate supplementation of 1.36 and 0.96 ( $\mathrm{kg}$ of milk/ $/ \mathrm{kg}$ concentrate) for cows grazing at low and high pasture allowances. Robaina et al. (1998) obtained responses ranging from 0.81 to 1.56 accompanied by a linear improvement in protein concentration of $0.36 \mathrm{~g} / \mathrm{kg}$ per kilogram of concentrate DM varying from 1.8 to $6.7 \mathrm{~kg}$ of DM per day. Reis and Combs (2000) obtained responses to concentrate supplementation of 1.0 and $0.86(\mathrm{~kg}$ of milk/ $/ \mathrm{kg}$ of concentrate $\mathrm{DM})$ for cows supplemented with 5 and $10 \mathrm{~kg}$ of concentrate daily. Walker et al. (2000) concluded that response of FCM of $1.1 \mathrm{~kg} / \mathrm{kg}$ of cereal based concentrate DM can be achieved when fed twice daily and at rates up to $3 \mathrm{~kg}$ of DM/day to dairy cows grazing restricted amounts of paspalum-type pasture in Autumn. Delaby et al. (2001) obtained an average response of $1.04 \mathrm{~kg}$ of milk per kilogram of concentrate DM, and this response was linear from a supplementation level of between $4 \mathrm{~kg}$ and $6 \mathrm{~kg} / \mathrm{d}$. The slightly lower response in MP2 $(0.94$ $\mathrm{kg}$ of milk per kilogram of concentrate DM) is expected because of cows' lower energy requirement at this time (Journet and Demarquilly 1979). Because the reviews by Leaver et al. (1968) and Journet and Demarquilly (1979), the genetic merit of dairy cows has increased appreciably, and this is evident in the difference in the level of milk production in the studies. Consequently, it is much more difficult to meet the energy requirements of the high yielding dairy cows at pasture.

The negative coefficient for DIM was expected, as maximum milk yield normally occurs between wk 5 and 7 of lactation (Bines, 1976). The magnitudes of the coefficients are very much in line with those expected with normal lactation profiles. The effect of parity was large, especially in early lactation and was similar to that observed previously (Buckley et al., 2000).

In the present study the observed GDMI was a function of PMY, PBW, CI, DIM, and LN. Higher yielding cows have a greater nutrient demand, and this is reflected in increased grass intake (Grainger et al., 1985; Gordon et al., 1995; Buckley et al., 2000). The partial regression coefficients of 0.12 and $0.19 \mathrm{~kg}$ increase in GDMI per kg of PMY obtained in the present study are similar to the 0.16 obtained by Bines et al. (1977) and 
Table 8. A selection of models for predicting milk production and grass DM intake (GDMI) from a combination of independent variables in measurement period $2($ MP2) $(n=198)$.

\begin{tabular}{|c|c|c|c|c|}
\hline Equations & Milk yield (kg) & Milk protein $(\mathrm{kg})$ & Milk fat (kg) & GDMI $(\mathrm{kg})$ \\
\hline PMY (kg/cow/d) ${ }^{1}$ & $0.440(* * *)$ & & $\ldots$ & $0.190(* * *)$ \\
\hline PMP (kg/cow/d) & $\ldots$ & $0.428(* * *)$ & $\ldots$ & $\ldots$ \\
\hline PMF (kg/cow/d) & $\ldots$ & $\ldots$ & $0.251(* * *)$ & \\
\hline PBW (kg) & $\ldots$ & $\ldots$ & & $0.007(\dagger)$ \\
\hline $\mathrm{CI}(\mathrm{kg} \mathrm{DM})^{2}$ & 1.16 (***) & $0.044(* * *)$ & $0.031(* * *)$ & -0.444 (***) \\
\hline GDMI $(\mathrm{kg} / \mathrm{cow} / \mathrm{d})^{3}$ & $0.497(* * *)$ & 0.015 (***) & $0.0135(* *)$ & \\
\hline DIM & $-0.033(* * *)$ & $-0.0007(* *)$ & $-0.0007(*)$ & $-0.011 （ \dagger)$ \\
\hline LN 1 & -1.400 (***) & $-0.0647(* * *)$ & -0.054 (***) & -2.088 (***) \\
\hline LN 2 & $0.844(* * *)$ & $0.0386(* * *)$ & $-0.048(* * *)$ & $-0.162(* * *)$ \\
\hline LN 3 & $0.556(* * *)$ & $0.0260(* * *)$ & $0.0063(* * *)$ & 2.249 (***) \\
\hline Intercept & 7.815 & 0.268 & 0.468 & 13.85 \\
\hline $\mathrm{R}^{2}$ & 0.639 & 0.716 & 0.406 & 0.570 \\
\hline $\mathrm{RSD}^{4}$ & 2.274 & 0.069 & 0.105 & 1.788 \\
\hline
\end{tabular}

${ }^{1} \mathrm{PMY}, \mathrm{PMP}, \mathrm{PMF}$, and PBW = Average production figures for wk 5, 6, 7, and 8 of lactation in 1998, for milk, protein, fat, and BW.

${ }^{2} \mathrm{CI}=$ Concentrate intake.

${ }^{3} \mathrm{GDMI}=$ Grass DM intake.

${ }^{4} \mathrm{RSD}=$ Residual standard deviation.

$\dagger P \leq 0.10$.

$* P \leq 0.05$.

$* * P \leq 0.01$.

$* * * P \leq 0.001$.

the 0.13 obtained by Conrad et al. (1964). The partial regression coefficient for experimental milk yield varies from 0.43 to $0.47 \mathrm{~kg}$ of DM per kilogram of FCM (Stakelum and Connolly, 1987) to $0.25 \mathrm{~kg}$ of OM per kilogram of milk yield (Peyraud and Gonzalez-Rodrigez, 2001). Stakelum and Connolly (1987) stated that the theoretical energy requirement for milk production is $0.4 \mathrm{~kg}$ of DM per kilogram of FCM. However, Ostergaard (1979) considered milk yield an output factor and did not include milk yield for predicting DM intake. Milk yield is not known at the time of prediction. Consequently Peyraud et al. (1996) prefer to use preexperimental milk yield or potential milk yield for predicting DMI.

The increases of 0.6 and $0.7 \mathrm{~kg}$ of GDMI per $100 \mathrm{~kg}$ of PBW are lower than that reported previously for experimental BW (Conrad et al., 1964; Stakelum and Connolly, 1987). Models for predicting DMI with primiparous and multiparous cows generally have the lowest change in intake due to difference in BW (Coulon et al., 1989; Kristensen and Kristensen, 1987; Rook et al., 1991). This may be explained by the relatively lower intake capacity of primiparous cows (Ingvartsen, 1994). The intake capacity in the first part of lactation of primiparous cows calving at an age of $2 \mathrm{yr}$ and weighing $500 \mathrm{~kg}$ is only around $80 \%$ of that of multiparous cows, and only about two thirds of this difference can be explained in BW and milk yield (Jarrige, 1986). If parity is not taken into account, the unexplained part of the difference may be incorporated into the parameter for $\mathrm{BW}$, which is then increased.
The substitution rates, 0.54 and $0.44 \mathrm{~kg}$ of grass per kilogram of concentrates, obtained in the present study is lower than that reported previously (Leaver et al., 1968; Stakelum, 1988). This is particularly significant because previous results showed that substitution rates are highest when GDMI and digestibility are high (Stakelum et al., 1988). However more recent studies have shown lower substitution rates (Robaina et al., 1998; Bargo et al., 2000; Reis and Combs, 2000). Robaina et al. (1998), using the n-alkane technique obtained substitution rates of 0.3 and $0.6 \mathrm{~kg}$ of DM reduction in pasture intake/kg of DM grain consumed at low and high pasture allowances. Bargo et al. (2000) using the $\mathrm{Cr}_{2} \mathrm{O}_{3}$ as fecal indicator obtained substitution rates of 0.26 and $0.55 \mathrm{~kg}$ of DM reduction in pasture/kg of concentrate DM consumed at low and high pasture allowances. Faverdin (1991), showed that the substitution rate is lower with high yielding dairy cows when the energy requirements of the animal are not being met. In these situations, concentrate only slightly reduces grass intake and appreciably influences the energy balance of the animals, which results in increased animal performance (Coulon and Remond, 1991). The most limiting nutrient in most grazing situations is energy supply (Muller and Fales, 1998). Concentrate supplementation increases energy intake and thereby increases rumen fermentation and microbial protein synthesis, which in turn contributes to optimize DMI. The positive effect of DIM in early lactation and the negative effect in late lactation are expected given that maximum intake is achieved at about $100 \mathrm{~d}$ postcalving 
(Brown et al., 1977). Bines (1979) observed mean intake values of $13.7,15.8$, and $16.7 \mathrm{~kg}$ for first-, second-, and third-lactation cows, respectively. The relative values for first-lactation cows were much larger in the present study especially in early lactation. The probable reason for the difference is that the age at first calving was approximately $24 \mathrm{mo}$, while the age at first calving is greater in most other systems of milk production.

\section{CONCLUSIONS}

This study indicates that with high yielding dairy cows in early lactation on pasture only, GDMI of $17 \mathrm{~kg}$ can be achieved supporting milk production of $30 \mathrm{~kg} /$ d, under good grazing conditions. Parity, PMY, PBW, CI, and DIM had a significant effect on GDMI. The results suggest that concentrate supplementation of high yielding dairy cows at pasture will result in lower substitution rates ( 0.4 to $0.6 \mathrm{~kg}$ reduction in GDMI $/ \mathrm{kg}$ increase in concentrate DM intake), and higher milk yield responses ( $>1.0 \mathrm{~kg}$ milk/kg of concentrate DM) than previously published with lower yielding dairy cows.

\section{ACKNOWLEDGMENTS}

The authors wish to acknowledge the staff at Curtins Farm for their cooperation, care and management of the experimental animals. We would especially like to thank Michael Feeney for his patience and help during the measurement periods and the many students who assisted us daily. The technical assistance of F. Flynn, M. Kearney, J. Dwyer, J. Flynn, J. Nash, and N. Galvin and the partial funding of this project by the Irish Dairy Farmers EU structural funds and laws are also acknowledged.

\section{REFERENCES}

Bargo, F., L. D. Muller, J. E. Delahoy, and T. W. Cassidy. 2000. Milk response to concentrate supplementation of high producing dairy cows grazing at two pasture allowances. J. Dairy Sci. Vol. 83, Suppl. 1/2000.

Bines, J. A. 1976. Regulation of food intake in dairy cows in relation to milk production. Livest. Prod. Sci. 3:115-128.

Bines, J. A., D. J. Napper, and V. W. Johnson. 1977. Long term effects of level of intake and diet composition on the performance of lactating dairy cows. 2. Voluntary intake and ration digestibility in heifers. Proc. of the Nutrition Society, 36:146A. (Abstr.).

Bines, J. A. 1979. Voluntary food intake. Pages 23-48 in Feeding Strategy for the High Yielding Dairy Cow. W. H. Broster, R. H. Philipps and H. Swan, eds. Granada Publishing Ltd., Frogmore, St. Albans, UK.

Brown, C. A., P. J. Chandler, and J. B. Holten. 1977. Development of predictive equations for milk yield and dry matter intake in lactating cows. J. Dairy Sci. 60:1739-1754.

Buckley, F., P. Dillon, S. Crosse, F. Flynn, and M. Rath. 2000. The performance of Holstein-Friesian dairy cows of high and medium merit for milk production on grass based feeding systems. Livest. Prod. Sci. 54:107-119.
Buckley, F., P. Dillon, J. F. Mee, R. Evans, and R. F. Veerkamp. 2000. Trends in genetic merit for milk production and reproductive performance. Pages 43-59 in Proc. of Teagasc National Dairy Conference 2000. Dairying 2000-Opportunities for the New Millennium, Silver Springs Hotel, Cork, Ireland.

Byrant, A. M., and T. E. Trigg. 1981. Progress report on the performance of Jersey cows differing in breeding index. Proc. N.Z. Soc. Anim. Prod. 41:39-43.

Clancy, M. J., and R. K. Wilson. 1966. Development and application of a new chemical method for predicting the digestibility and intake of herbage samples. Pages 445-452 in Proc. of the Tenth International Grassland Congress, Helsinki.

Conrad, H. R., A. D. Pratt, and J. W. Hibbs. 1964. Regulation of feed intake in dairy cows. 1. Change in importance of physical and physiological factors with increasing digestibility. J. Dairy Sci. 60:1725-1733.

Coulon, J. B., A. Hoden, P. Faverdin, and M. Journet. 1989. Dairy cows. Pages 73-91 in Ruminant Nutrition: Recommended Allowances and Feed Tables. R. Jarrige, ed. INRA, Paris, France.

Coulon, J. B., and B. Remond. 1991. Variations in milk output and milk protein content in response to the level of energy supply to the dairy cow: A review. Livest. Prod. Sci. 29:31-47.

Delaby, L., J. L. Peyraud, and R. Delagarde. 2001. Effect of the level of concentrate supplementation, herbage allowance, and milk yield at turn out on the performance of dairy cows in mid lactation at grazing. Anim. Sci. 73:171-181.

Dillon, P. 1993. The use of n-alkanes as markers to determine intake, botanical composition of available or consumed herbage in studies of digesta kinetics with dairy cows. Ph.D. Thesis, National University of Ireland, Dublin, Ireland.

Dillon, P., S. Crosse, G. Stakelum, and F. Flynn. 1995. The effect of calving date and stocking rate on the performance of springcalving dairy cows. Grass Forage Sci. 50:286-299.

Dillon, P., and G. Stakelum. 1989. Herbage and dosed alkanes as a grass measurement technique for dairy cows. Ir. J. Agric. Res. 28:104 (Abstr.).

Dove, H., and R. W. Mayes. 1991. The use of plant wax alkanes as marker substances in studies of the nutrition of herbivores: A Review. Aust. J. Agric. Res. 42:913-952.

Faverdin, P., J. P. Dulphy, J. B. Coulon, R. Verite, J. P. Garel, J. Rouel, and B. Marquis. 1991. Substitution of roughage by concentrates for dairy cows. Livest. Prod. Sci. 27:137-156.

Gordon, F. J., D. C. Patterson, T. Yan, M. G. Proter, C. S. Mayne, and E. F. Unsworth. 1995. The influence of genetic index for milk production on the response to complete diet feeding and the utilization of energy and protein. Anim. Sci. 61:199-210.

Grainger, C. A., W. F. Davey, and C. W. Holmes. 1985. The performance of Friesian cows with high and low breeding indexes. Anim. Prod. 40:379-388.

Hoden, A., J. L. Peyraud, A. Muller, L. Delaby, P. Faverdin with the collaboration of J. R. Peccatte, and M. Fargetton. 1991. Simplified rotational grazing management of dairy cows: effects of rates of stocking and concentrate. J. Agric. Sci. (Cambridge) 116:417-428.

Holmes, C. W. 1988. Genetic merit and efficiency of milk production by the dairy cow. Pages 195-215 in Nutrition and Lactation in the Dairy Cow. P. C. Garnsworthy, ed. Butterworths, UK.

Hutchings, N. J. 1991. Spatial heterogeneity and other sources of variance in sward height as measured by the sonic and the HFRO sward sticks. Grass Forage Sci. 46:277-282.

Ingvarsten, K. L. 1994. Models of voluntary food intake in cattle. Livest. Prod. Sci. 39:19-38.

International Dairy Federation. 1993. Milk: Determination of Nitrogen content. Brussels: IDF (FIL-IDF Standard no. 20B).

Jarrige, R., C. Demarquilly, J. P. Dulphy, A. Hoden, J. Robelin, C. Berenger, Y. Geay, M. Journet, C. Malterre, D. Micol, and M. Petit. 1986. The INRA fill unit system for predicting the voluntary intake of forage based diets in ruminants: A review. J. Anim. Sci. 63:1737-1758.

Journet, M., and C. Demarquilly. 1979. Grazing. Pages 295-321 in Feeding Strategy for the High Yielding Cow. W. H. Broster and H. Swan eds. Granada Publishing Limited, Frogmore, St. Albans, UK. 
Kennedy, J., P. Dillon, P. Faverdin, L. Delaby, F. Buckley, and M. Rath. 2002. The influence of cow genetic merit on response to concentrate supplementation in a grass based system. J. Anim. Sci. 75:433-446.

Kristensen, V. F., and T. Kristensen. 1987. Pages 9-11 in Vurdering og justering af foderoptagelsessystemet til malkek er. Annual meeting, Nat. Inst. Anim. Sci. Foulum, Denmark.

Leaver, T. D., R. C. Campling, and W. Holmes. 1968. use of supplementary feeds for grazing dairy cows. Dairy Sci. Abstr. 30:355361.

Lowman, B. G., N. Scott, and S. Somerville. 1976. Condition scoring of cattle. rev. ed. Bull. of East Scotland College of Agric. No. 6.

Mayes, R. W., C. S. Lamb, and P. M. Colgrove. 1986. The use of dosed and herbage n-alkanes as markers for the determination of herbage intake. J. Agric. Sci. Cambridge 107:161-170.

Morgan, D. J., G. Stakelum, and J. Dwyer. 1989. Modified neutral detergent cellulase digestibility procedure for use with the "fibertec" system. Ir. J. Agric. Res. 28:91-92.

Muller, L. D., and S. L. Fales. 1998. Supplementation of Cool-season grass pastures for dairy cattle. Pages 335-350 in Grass for dairy cattle. J. H. Cherney and D. J. R. Cherney eds. CABI publishing, Wallingford, Oxon, UK.

O'Donovan, M. 2000. The relationship between the performance of dairy cows and grassland management on intensive dairy farms in Ireland. Ph.D. Thesis, University College Dublin, Ireland.

O'Kiely, P. 1994. The cost of feedstuffs for cattle. R \& H. Hall, Technical Bulletin, No. 6, 1994.

Ostergaard, V. 1979. Strategies for concentrate feeding to attain optimum feeding level in high yielding dairy cows. Page 138 in 482 Beretning fra statens husdyrbrugs forsog Kobenhavn 1979.

Peyraud, J. L., E. A. Comeron, M. H. Wade, and G. Lemaire. 1996. The effect of daily herbage allowance, herbage mass, and animal factors upon herbage intake by grazing dairy cows. Ann. Zootech. (Paris) 45:201-207.

Peyraud, J. L., and A. Gonzalez-Rodrigez. 2001. Relations between grass production, supplementation and intake in grazing dairy cows. Pages 269-282 in Grassland Science in Europe Vol. 5.

Robaina, A. C., C. Grainger, P. Moate, J. Taylor, and J. Stewart. 1998. Responses to grain feeding by grazing dairy cows. Aust. J. Exp. Agric. 38:541-549.
Rook, A. J., M. Gill, R. D. Willink, and S. J. Lister. 1991. Prediction of voluntary intake of grass silage by lactating cows offered concentrates at a flat rate. Anim. Prod. 52:407-420.

Reis, R. B., and D. K. Combs. 2000. Effects of increasing levels of grain supplementation on rumen environment and lactation performance of dairy cows grazing grass legume pasture. J. Dairy Sci. 83:2888-2898.

SAS. 1991. SAS/STAT User's Guide, SAS Inst. Inc., Cary, NC.

Snedecor, G. W., and W. G. Cochran. 1980. Statistical Methods. 7th ed. Iowa State University Press, Ames, IA.

Stakelum, G., and J. Connolly. 1987. Effect of body size and milk yield on intake of fresh herbage by lactating dairy cows indoors. Ir. J. Agric. Res. 26:9-22.

Stakelum, G., P. Dillon, and J. Murphy. 1988. Supplementary feeding of grazing dairy cows. Pages 25-27 in Proc. Moorepark Dairy Conference, Teagasc, Dublin 4, Ireland.

Stakelum, G., and P. Dillon. 1990. Influence of sward structure and digestibility on the intake and performance of lactating and growing cattle. Pages 30-42 in Management Issues for the Grassland Farmer in the 1990s. C. S. Mayne, ed. Occasional Publication No. 25, British Grassland Society, Hurley, UK.

Tyrell, H. F., and J. T. Reid. 1965. Prediction of the energy value of cow's milk. J. Dairy Sci. 48:1215-1223.

Ulyatt, M. J., and G. C. Waghorn. 1993. Improving the quality and intake of pasture based diets for lactating dairy cows. Page 1131 in Occasional Publication No. 1, Massey University, New Zealand.

Van Arendonk, J. A. M., G. J. Nieuwhof, H. Vos, and S. Korver. 1991. Genetic aspects of feed intake and efficiency in lactating dairy heifers. Livest. Prod. Sci. 29:263-275.

Van Soest, P. J., R. H. Wine, and L. A. Moore. 1966. Estimation of the true digestibility of forages by the in vitro digestion of cell wall. Pages 438-441 in Proc. 10th Int. Grassland Congress, Helsinki, Finland.

Veerkamp, R. F., G. Simm, and J. D. Oldham. 1994. Effects of interaction between genotype and feeding system on milk production feed intake, efficiency and body tissue mobilization in dairy cows. Livest. Prod. Sci. 39:229-241.

Walker, G. P., C. R. Stockdale, W. J. Wales, P. T. Doyle, and D. W. Dellow. 2001. Effect of level of grain supplementation on milk production responses of dairy cows in mid-late lactation when grazing irrigated pastures high in paspalum (Paspalum dilatatum Poir.). Aust. J. Exp. Agric. 41:1-11. 